\title{
Oral Literature and Development of West Sumatra: Reconstructing the Minangkabau Cultural Values through Role and Position of Women in Kaba at Dendang Pauah Show
}

\author{
Refisa Ananda, Farel Olva Zuve \\ Universitas Negeri Padang \\ anandarefisa@gmail.com
}

\begin{abstract}
This research was motivated by the assumption that kaba in the oral literary performance of Dendang Pauah can be used to reconstruct the cultural values or view of the Minangkabau life. Knowledge of the cultural values of a collective is very important, because with that knowledge we will be able to judge whether his or her views are compatible or not with the soul of development. Kaba reveals to us implicitly, how his people think. It is also through kaba, which is an oral literature, a collective perpetuating or expressing what is felt to be important to its people at some time. The purpose of this study was to describe the cultural values contained in kaba at the oral literary performance of Dendang Pauah. This study used descriptive qualitative method. The data techniques collection used in this study include interviews, recording, direct observation, and field notes. Participants in this study were dendang player, saluang player, Dendang Pauah's experts or community leaders of Koto Panjang Ikua Koto Village, Koto TangahDistrict, Padang City. Additional participants are spectators and community of Koto Panjang Ikua Koto Village, Koto Tangah District, Padang City. The research was conducted in Koto Panjang Ikua Koto Village, Koto Tangah District,Padang City. The object of this research is kaba which is delivered in oral literary performance of Dendang Pauah that is Kaba Urang Tanjuang Karang
\end{abstract}

Keywords--Oral Literature, Kaba, Cultural Values

\section{INTRODUCTION}

The importance of storytelling as the foundation of human experiences cannot be overestimated. The oral traditions focus upon educating and transmitting knowledge and skills and also evolved into one of the earliest methods of communicating scientific discoveries and developments (High \& Hardy, 2011, p. 408).

Damono $(2003$, p. 2) reveals that literary works display a picture of life, and life is a social reality. It is this that causes the existence of a literary work can not be regarded as the result of imagination alone.Oral literature as part of the culture contains ideas and is full of values that are beneficial to the nation's development. Oral literature as a cultural treasure of each region must have values that are still relevant to the society today. Rusyana (1984, p. 282-283) says that we need an in-depth knowledge of local literature in order to gain insight into the various aspects of our lives.

$K a b a$ is one of the classic literary works of Minangkabau society in the form of prose which contains the reality of Minangkabau society life (Wulandari, 2015, p. 56). Kaba in the Dendang Pauahshowis one of oral literature in Minangkabau containing moral education messages, in addition to its main function as an entertainment. In its society, oral literature has an important function, not merely as an entertainment but more importantly as a means of education, as a center of communication, and in some respects also for the soial status competition of its audience (Amir, 2013, p. 17).

Djamaris (2002, p. 4) says that at first the Minangkabau literary life was of oral literature, literature delivered from mouth to mouth. Storytelling has long served as an important means of transmitting cumulative culture and traditional ecological knowledge (TEK), especially in the absence of books and other means of information storage (Schniter dkk., 2018, p. 102). The story is memorized by the storyteller (kaba teller) and then sang by kaba teller to the listener. One form of the oral literature kaba presentation is Dendang Pauah.

Dendang Pauah is the name of a variety of Minang storytelling tradition that tells a certain group of kaba which is appreciated by the Pauah community, the eastern suburb of Padang Municipality and the surrounding areas. A performance of Dendang Pauah is played by at least two people: one musician called a saluang player, and a storyteller called a dendang player.

The diversity on tribes that we have in this country is one of the elements of the formation of the Unitary State of Indonesian Republic. One of the tribes that has the largest population and has historical cultural values in Indonesia is the Minangkabau tribe. The Minangkabau tribe is a tribe originating from West Sumatra. Minangkabau ethnic is ethnically submissive and obedient to the cultural values derived from their ancestors. This can be seen from the result of such studies as conducted by Rusli (2005) explains that ethnic Minangkabau quite paternal istic and loyal to the culture and leaders. 
According to Chamamah (in Karyanto, 2008, p. 45), in every texts of the past, whether documented in writing or in the form of oral tradition, various information about life, ideas, beliefs, religious life, customs, moral teachings and the ever-growing outlook on life and developed in the past Nusantara society. Therefore, the number of relics of the past for the Indonesian nation actually brings a very big advantage for the effort to build the culture and character of the nation. It is said that because through the texts of the past is open the possibility for the nation of Indonesia to explore the record of various humanitarian and cultural problems that have occurred so that it can be a provision of learning in the nation's cultural development efforts in the future.

Development can be seen from two important parts, namely physical and psychic. Both are important, but the most important is the psychic part, because without any mental preparation and desire to move forward, physical development will be difficult to do, or at least will experience obstacles and not running smoothly. In this study, which I will make the object of research is a part of culture in the form of oral literature. Through the cultural research contained in kaba oral literature in Dendang Pauah performances, we can find out whether their traditional cultural values are appropriate or not to the cultural values of the Indonesian nation, which are based on Pancasila and development. If appropriate, this can be useful to fill the value of Indonesian national culture. In this way the West Sumatera culture can contribute to the development of Indonesian culture.

In terms of anthropology, the culture can be examined through three aspects, namely (1) culture as a behavior; (2) culture as human behavior; and (3) culture as the result of human behavior (Koentjaraningrat in Pudentia, 2008, p. 72). If linked to development, then development behavior will be realized if supported by a developmental behavior. According to Danandjaja (in Pudentia, 2008, p. 72), developmental behavior is in the form of ideals, norms, views, laws, rules, beliefs, attitudes, etc, all of which are to improve their lives, whether physically or mentally a collective.

Value is a human psychic phenomenon that considers something useful and valuable in its life, so one voluntarily engages both physically and mentally into the phenomenon (Syuhada, et al., 2018, p. 191). Minangkabau is one of the largest ethnic groups in Indonesia, which has a matrilineal kinship system. In the matrilinal Minangkabau kinship system, women get a different position when compared with women in patrilineal societies. When carefully scrutinized, matrilineal culture actually contains the values of equality and justice, both in the order of philosophy, structure, and implementation should be (Fatimah, 2012, p. 11).

\section{METHODS}

This study applied descriptive-qualitative method. Research is not limited to the collection and compilation of data, but includes the analysis and interpretation of the data (Surakhmad, 1994, p.139). The data techniques collection used in this study, include interviews, recording, direct observation, and field notes. The participants in this study were the dendang players, saluang player, Dendang Pauah's experts or community leaders of Koto Panjang Ikua Koto Village, Koto Tangah District, Padang City. Additional participants were spectators, and the community of Koto Panjang Ikua Koto Village, Koto Tangah District, Padang City. The research was conducted in Koto Panjang Ikua Koto village, Koto Tangah District, Padang City. The object of this research was kaba which is usually delivered in oral literary performance of Dendang Pauah that is Kaba Urang Tanjuang Karang.

\section{FINDING AND DISCUSSION}

The Kaba text in the Dendang Pauah show is in the form of pantun and talibun. In one stanza there are 4 arrays, 6 arrays, 8 arrays, 12 arrays, 14 arrays, and 22 arrays. Kaba Urang Tanjuang Karang consists of pantun (consisting of 4 lines) and talibun (more than 4 lines, ranging from 6-22 lines). The number of arrays in each stanza is always an even number. For example, one stanza consists of 4 arrays, then arrays 1 and 2 are part of sampiran and arrays 3 and 4 are part of $i$ si (content), and so on. Kaba Urang Tanjuang Karang consists of 506 stanzas or 2281 lines. There are 397 verses of rhyme consisting of four lines. There are as many as 87 verses of rhyme consisting of 6 arrays. There are as many as 10 verses of rhyme consisting of 8 arrays. There are as many as 3 verses of rhyme consisting of 12 arrays. There are as many as 2 verses of rhyme consisting of 14 arrays. There are 1 stanza pantun consisting of 22 arrays. The content of the pantun in the kaba text of Dendang Pauah can be divided into two. First, in relation to things outside kaba are told about the audience, the host, the introduction, the transition episode, and the cover. Second, this is directly related to the story (picture of the character's journey, character's character, etc.).

Background of the place featured in Kaba Urang Tanjuang Karang refers to one of the areas on Sumatra island, which is in Kaliawi, Tanjung Karang, this area is the place of origin of the characters in this story. Palembang as a place to wander the figures of Delima and the secretary, Angku Guru, Unyiang and Syamsudin, and Amak Delima, and Bandung as a place to study for Syamsudin. The figures raised in Kaba Urang TanjuangKarang are eleven people, namely Amak Delima (Pical seller's aunt), Abak Delima (Malin), Siti Delima, Syamsudin, Siti Rohani, Amak Rohani, Amak Lapau, Angku Guru, Unyiang, the secretary, the secretary's Apak. The following will be explained each female characters and Minangkabau cultural values contained in Kaba Urang Tanjuang Karang. 
a. Amak Delima (Bibi Tukang Pical)

Amak Delima is the first wife of Abak Delima (Malin) and also the biological mother of Siti Delima and Syamsudin. There is no physical feature of Amak Delima in this kaba. She was raised at the beginning of the story, in the middle of the story, and a bit at the end of the story when she was reunited with her two children she had abandoned.

At the beginning of her marriage to Abak Delima, she had time to live in poverty. At that time she was still steadfast and patient. She was willingto accept her husband for what he is. In such difficult conditions she remained obedient and obeyed her husband.

urang Cino bali lah sendok

pangaka nasi dalam pinggan

iyo saiyo untuang elok

dek lai turuik manuruik an

Thanks to the patience and fortitude of this husband and wife, Abak Delima finally got a permanent job at the train station. Abak Delima receives a salary every month and the money is handed over Amak Delima. Amak Delima is very happy. It is at this point that their lives are getting better and all of their needs are fulfilled. However, the situation did not last long. While sleeping, Amak Delima had nightmares and had a feeling that something bad would happen to their family. She cries for her fate and advises her children not to be spoiled. She was afraid of the misfortune that might befall her family. It turns out that Abak Delima is married to another woman. This incident makes Amak Delima are so disappointed and sorry.

After abandoned by Abak Delima, Amak Delima and her two children live in distress. So often mortgaging and selling her valuables to the pawnshop to fulfill daily needs, but all that is still not enough. They eat as sober, often not even eat at all. In this section she is portrayed as a strong woman, still trying to nurture her children although being abandoned by her husband. Amak Delima still survives with that condition in hopes that Abak Delima returns with them again.

\section{buruang balam tabang ka ladang \\ inggok kaateh batang jambak \\ salamo Malin indak pulang, Nceee \\ kadok Amak Delima pai ka pajak}

One day Amak Delima got a letter from Abak Delima. At first she was so happy to hope that it was money sent or news from her husband. In fact, it was a divorce letter from Abak Delima. It made her so sad and feels deeply desperate. Disappointment she felt she could not dammed. She became weak and could no longer think clearly. It was then that she was seduced by Satan's seduction. So had intended to commit suicide and also killed her two children.

Finally after her heart began to calm down, she regained consciousness. She did not commit suicide and kill her children. Faced with such a painful reality, the character of Amak Delima preferred to leave her children at home while she went to try her fortune. As a mother, Amak Delima had the heart to leave her children who still so small. A mother's love affection strand just like that. Her agony and resentment to the irresponsible Abak Delima also made her escape from reality. She felt that she would not be able to support her children. So she hopes that her children can live from the pity of the villagers.

Based on some quotes and the description above, it can be seen that Amak Delima as a woman who still depends on the husband. She always cries for fate. Not trying to change and find a way out. Escape from the reality of life and unable to solve the problems she faces wisely.

\section{b. Siti Delima}

Siti Delima is the daughter of Abak Delima and Amak Delima, and Syamsudin's brother.At first, she grew up in a poor family, then when her father had found a permanent job, $\mathrm{s}$ he, her mother, and her brotter began to feel happiness. But it did not last long. Her father married another woman. Be a child who lives in pain and suffering with her mother and her little brother.

She is a strong sister and has positive thinking. When she first woke up and her little brother asked where their mother was, she thought her mother went to prayer. Then she went to the river. She is a sister who can be used for his brother. She is nurturing her brother well. After arriving at the river, she bathed her brother and then herself. Delima always prioritize the needs of her brother first then herself. 
antah kok Amak pai sumbayang, nyo Dik

marilah kito pai pulo

talang di lurah tapi banda

nyo gatia anak rang di kelok

babimbiang adik jo nan kida

baganggam cerek jo nan suok

Delima is a girl who is always grateful and appreciates the help of others. This is seen when she was assisted by Amak Lapau and invited to live in lepau. In addition to residence she was also given food. At that time Delima was very grateful because she no longer knew who to complain to whom. Her father had left, her mother had also run away left her alone with her brother.

lah masak buah limau puruik

ka ubek anak rang di duku

amak marewai dagang anyuik, mak eii

tarimo kasih labih daulu

Delima is very diligent and knows repayment. After being assisted by Amak Lapau, she wakes up early, fries fried food and peddles it around the village.

Salasa balai rang Solok bakadai anak rang Talang

rang manjua jo mambali

sudah makan lah bih lalok

lalok salayang ari siang

Delima manggoreang pagi-pagi

As an older sister, Delima is a loving sister. Everytime before she peddles fries, she is always given 2 free fries. One was given to her brother, while her quota was sold in order to buy new clothes for a substitute for her ugly brother's clothes. She was willing to sacrifice to buy new clothes for her brother.

kayu kalek di dalam lading

di balik batang asam sewa

enggeran buruang layang-layang

nan ciek makan lah dek waang

dek one untuak ka bajua, Syamsudin

ka pangganti baju buruak bujang

Delima is also very grateful to Angku Guru who has raised her younger brother Syamsudin into a child. That way she believes that Syamsudin will have a better life. Education is met, needs are fulfilled. She is more concerned with her brother than herself. As a sister, she wants the best for her only brother.

talang di lurah tapi banda

di baliak batang dalu-dalu

o nyo bujuak adik dek Delima

pai lah waang jo Angku guru, diak eii

lah tabang buruang barau-barau

inggok di ateh si anajalai

pai jo one pi ka lapau nyo Syamsudin

manggaleh goreang nan ka pandai

She was a strong and wise woman, when Syamsudin said goodbye to move with Angku Guru to Palembang, she sincerely took off her brother. She is willing to be separated from her only remaining family member. Just so her brother can be a successful person. If he stayed with her, she could not promise anything for her brother.

In her household life with the secretary, she was very obedient to her husband, wherever her husband was moved to she also follow him. Shedoes not want any problems in his household. 
buruang kekek tabang ka ladang

manyasok minum ka tapian

manga basabuik ka Palembang da

kabalik itu mbo turuik an

She is a patient and calm person. During her quarrel with the secretaryshe tried to explain the problem sit perfectly. She tried to resolve the misunderstanding of the secretary accusing her of having an affair.

latik-latik tabang ka parak

inggok di ateh marapalam

sajak pagi dek sisalak

nyo jawek sae tangah malam

She only cried when the secretary had threatened to beat her. The harshness of life and the bitterness of the reality of her life made her a strong woman. Finally she and the secretary get divorced.

c. Siti Rohani

Siti Rohani is the second wife of Malin (Abak Delima) and daughter of Amak Rohani. As Malin's wife, at the beginning of her marriage Rohani treated Malin well according to her mother's advice. Although she is already become a wife, she is described as a woman who is not independent. She followed all her mother's words. The shopping money left by her husband was handed over to her mother.

lah masak padi rang Jati

nyo makan buruang katitiran

ringgik nyo tarik dek Rohani

ka Amak kepeang baagiahan

Rohani is not firm in her attitude when she denies her mother who told her to divorce Malin. She prefers to lose a husband instead of having to be kicked out of her mother's house. Even so, she was still trying to persuade her mother to think clearly before facing the problem that happened to her husband. She still remembers all the service and kindness of Malin. She is afraid of villagers thinking badly to her mother. Before her husband was treated well, but after he was not working again he was dumped away.

\section{d. Amak Rohani (Mertua)}

Amak Rohani character is the mother-in-law of Malin (Abak Delima) from his second wife Siti Rohani. Amak Rohani only appears slightly in this kaba that is on the part of the story of marriage and Malin and Rohani's domesticlife. It can be concluded that Amak Rohani is just an extra figure in this Kaba. Amak Rohani is portrayed as a figure who is too involved in financial affairs in her child's household. As soon as her son-in-law went to work, she immediately told her daughter to look under the pillow how much money left by her son-in-law. Disappointed with the amount of money her son-in-law gave,she taught her daughter to behave better to her husband. It is also intended so that her son-in-law forgets his first wife so that all of his son-in-law's salaries will belong to her child as a whole.

Sinayan balai Kurai Taji bakadai anak Pauah Kamba

jerak bajerong pakadaian

lai gak coga Amak pandangi, Rohani

cubo lah liek baliak banta, Nak eii

bara balanjo rang tinggaan

........

buruang balam tabang ka parak

sadang manggungguang rangkai padi

kama kolah ka inggoknyo

co iko urang bakeh awak, mah Nak

cubo gak pandai basuami Rohani

buliah taroroh ka wak kito

Early in her daughter's household life with Malin, she treated Malin well. Amak Rohani is also very materialist. She agrees her daughter becomes the second wives because that her daughter's husband has a great salary. 
As a mother, Amak Rohani too regulates the life of a Malin (Abak Delima) household with Siti Rohani. She is portrayed as an authoritarian mother figure. She imposed her will and opinion to Rohani. This is seen when this character faces the fact that Malin has been discharged from his job and starts hanging out with thugs and gambling. She forced her daughter to get divorced with Malin immediately. Nothing more could be expected from her son-in-law. It will only bother her. She was so angry when her daughter denied her words. In fact, she expels Rohani instantly because she feels Rohani can not be advised and disobeyed to the parents.

She also said that there are still many men who still want to marry her daughter.Amak Rohani seems to underestimate the meaning of a marriage. In this quotation it is also seen that the criterion of a prospective son-in-law who is important to Amak Rohani is to have possessions. Jambi merchants and people of rank here mean people who have money and are materially dependable.

\author{
kabara bana panjang palupuh \\ sameter tigo gak jari \\ pandindiang rumah nan di subarang \\ kabara bana ati rusuah, nyo Naak \\ tigo bulan sapuluah hari, nyo Nak \\ gagah dari inyo nan ka datang \\ basauk mandi katabek \\ ari manjalang tinggih ari \\ kok indak dapek urang bapangkek \\ saudagar jambi banyak kini
}

Amak Rohani really does not want to return the favor. Malin who has no job, has nothing else will be thrown away. Seeing her daughter begat a rice for Malin she is angry, her miserliness appears here. She does not want her rice to be wasted for the useless and beneficial person for her. There is no physical representation of the Amak Rohani figure in this kaba.

\title{
Lah masak padi rang Lolong nyo tuai anak rang di Ampang bakao bareh ka ditekong amak mancubik di balakang
}

masuak ka dalam pakadaian ka pulang ari pukua duo manga juo kau tanak an, Rohani e

ka maabih-abih bareh ambo

\section{e. Amak Lapau}

Amak Lapau is a figure who takes care of Delima and her brother Syamsudin before Syamsudin was appointed by the teacher. Concern that belonged to Mak Lapau seen when Delima and his brother Syamsudin cry and lament their mother's departure. As she passed in front of Delima's house, she asked what had happened. Her sincerity helped these two children to be proved by all her attitudes. Delima and Syamsudin are fed and sheltered. Though they have no blood relation and are not family.

barambuih angin barat dayo patah badarik daun pandan pailah ka lapau kaduonyo, nak

di lapau tak adoh kakurangan

As a neighbor, Mak Lapau is so concerned about the condition of these two children. Herpersonality that loves to help others selflessly is so thankful by Delima.

Mak Lapau's kindness is really felt by Delima. Moreover, every Delima peddles fried around the village, Mak Lapau also provide two free fries for Delima and Syamsudin.

di ujuang ladang limau kapeh

enggeran buruang katitiran

takalo Delima ka mangaleh 
goreang lai duo rang peraian

Delima was also raised by Mak Lapau until she finally married the secretary. She organizes Delima's wedding like Delima is her own daughter. She is also not arbitrary in choosing a mate for Delima. Amak Lapau invites her villagers to attend the wedding of the secretary and Delima. With humility she invites all her neighbors. She still hopes all her invitees can attend even with the simple menu.

latik-latik tabang ka parak

tabang manyisi-nyisi rimbo

antah ka makan antah indak ko kawan ei

baliek juo alek ambo

\section{f. Unyiang}

Unyiang is Angku Guru's wife. When Unyiang saw Angku Guru take Syamsudin to her house, she asked who the child was. But as a wife as long as it is good, she is not too contesting about it. She is a good wife. She serves her husband wholeheartedly. She prepares drink and food when her husband comes home from work.

kayu tanam balai rang guguak jerak bajerong pakadaian

bakao angku ka kaduduak

uniang lah baragak pi ka dalam

dendayu buruang sidendayu

manyasok minum masuak banda

uniang mauta kopi susu

roti nyo gomok jo mentega

Her marriage to Angku Guru was not granted by the child. Finally she raised Syamsudin like her own son. Syamsudin's education is also her top priority.

pagi-pagi ka Tanjuang Saba

ka pulang ari tinggih ari

babao kain bugih lamo

tamat di dasar basikola

Unyiang e indak juo sanang ati

baiyo duduak jo Angku nyo

.

basauak mandi ka tapian

ari manjalang pukua anam

barisuak pagi kito uluan, Ngku eei

sakola damang kito masuak an

She also asked Angku Guru to continue Syamsudin's education to demang school in Bandung. In order her son to be equal to others. She wants her son to get a good education.

kok lai rampak bungo rayo

dibalik batang kacang parang

luruik sularo ka pagaran

tangguang sikola ingan iko, mah ngku

nak samo anak jo urang

ka Banduang bana dikirinan

Syamsudin's departure to Bandung made Uniang sad. She who is not the biological mother feels so hard to part with her adopted child. Her love is genuinely sincere and unconditional. When she heard that Syamsudin had become a demang, she is so happy. Uniang has also prepared a thanksgiving event by slaughtering a large buffalo. Her pride in Syamsudin is enormous. Uniang is a mother's figure who cares about her son's future through good education. 


\section{CONCLUSION AND RECOMMENDATION}

Based on the female characters'srole and position in Kaba Urang Tanjuang Karang is obtained Minangkabau cultural values in line with the development. First, in facing life problems one must try to find the wisest way to avoid regret. Secondly, in everyday life, a person needs someone else to help him in various aspects of life for that harmony of relationships among others is worth keeping. Third, education is very important for a child, family and the environment is the determinant to fight for the acquisition of education by child. Fourth, deliberations are important to help provide an assessment of good or bad decisions that will be taken by someone. Fifth, wander is one of the ways that Minangnese people do to improve their way of life to a better direction, either to work or to go to school. So do not be surprised if Minangkabauethnic known as an educatedethnic. The advanced education system in Minangkabau gave birth to many experts and activists who played a role in the independence process in Indonesia in general and in West Sumatra region in particular.

\section{References}

Amir, A. (2013). Sastra lisan indonesia. Yogyakarta: ANDI.

Damono, S. D. (2003). Sosiologi sastra. Semarang: Magister Ilmu Susastra UNDIP.

Djamaris, E. (2002). Pengantar sastra rakyat Minangkabau. Jakarta: Yayasan Obor Indonesia.

Fatimah, S. (2012). Gender dalam komunits masyarakat minangkabau; teori, pratek, dan ruang lingkup kajian. Journal of gender studies, 2 (1), p. 11-24.

Haigh, C. and Pip Hardy. (2011). Tell me a story - a conseptual exploration of storytelling in healthcare education. Jurnal Nurse Education Today, 31 (4) May 2011 p. 408-411.

Karyanto, P., dkk. (2008). "Pembentukan karakter anak menurut teks cerita rakyat ranggana putra demang balaraja: kajian pragmatik sastra" Jurnal Penelitian Dinas Sosial 7 (1), April 2008 p. 45-53.

Pudentia, MPPS. (2008). Metodologi kajian tradisi lisan. Jakarta: Asosiasi Tradisi Lisan.

Rusli, Z. (2005). Majelis tigo tungku sajorangan: budaya Minangkabau dalam perubahan. Pekanbaru: Alaf Riau.

Rusyana, Y. (1984). Bahasa dan sastra dalam gamitan pendidikan. Bandung: Diponegoro.

Schniter, E. dkk., (2018). "Information transmission and the oral tradition: evidence of a late-life service niche for tsimane amerindians" Evolution and Human Behavior 39 p. 94-105.

Surakhmad, W. (1994). Pengantar penelitian ilmiah dasar dan metode teknik. Bandung: Trasito.

Syuhada, dkk. (2018). "Nilai dalam cerita rakyat suku Dayak Tunjung tulur aji angkat di Kutai Barat: kajian folklor" Jurnal Ilmu Budaya 2 (2) April 2018 p. 188-195.

Wulandari, Y. (2015). "Perempuan Minang dalam kaba Cindua Mato karya Syamsuddin St. Rajo Endah dan Memang Jodoh karya Marah Rusli” Jurnal Penelitian Humaniora, 16 (1), Februari 2015 p. 55-60. 